\title{
Spinaxinus (Bivalvia: Thyasiroidea) from sulfide biogenerators in the Gulf of Mexico and hydrothermal vents in the Fiji Back Arc: chemosymbiosis and taxonomy
}

\author{
P. GRAHAM OLIVER ${ }^{1}$, CLARA F. RODRIGUES ${ }^{2}$, ROBERT CARNEY ${ }^{3}$ \\ and SEBASTIEN DUPERRON ${ }^{4}$ \\ ${ }^{1}$ BioSyB, National Museum of Wales, Cathays Park, Cardiff, CF10 3NP, Wales, UK. \\ E-mail: graham.oliver@museumwales.ac.uk \\ ${ }^{2}$ Departamento de Biologia and CESAM, Universidade de Aveiro, Campus Universitário de Santiago, \\ 3810-193 Aveiro, Portugal. \\ ${ }^{3}$ Department of Oceanography and Coastal Sciences, Louisiana State University, Baton Rouge, LA 70803. \\ ${ }^{4}$ UMR 7138 (UPMC CNRS IRD MNHN), Systématique, Adaptation, Evolution, Université Pierre et Marie Curie, \\ 7, quai St. Bernard, bâtiment A, 75005, Paris, France.
}

SUMMARY: Two new species of the thyasirid genus Spinaxinus (S. emicatus Oliver n. sp. and S. phrixicus Oliver n. sp.) are described from the Gulf of Mexico and the southwest Pacific, respectively. Both are compared with the type species of the genus, the eastern Atlantic S. sentosus Oliver and Holmes, 2006. Living specimens from the Gulf of Mexico were retrieved from artificial sulfide bio-generators on the upper Louisiana Slope. Gill morphology and molecular markers from the symbiotic bacteria confirm that Spinaxinus is chemosynthetic and that the chemoautotrophic bacteria are related to sulfide oxidizing Gammaproteobacteria. Living specimens from the southwest Pacific were retrieved from hydrothermal vent sites in the Fiji and Lau Back Arc Basins. In the Atlantic Spinaxinus is now recorded from two anthropogenic situations and appears to be generally absent from natural cold seep sites and not yet recorded at any hydrothermal sites. The primarily anthropogenic distribution of Spinaxinus in the Atlantic is discussed with reference to the natural hydrothermal vent habitat of the Pacific S. phrixicus.

Keywords: Thyasiroidea, taxonomy, chemosymbiosis, anthropogenic settings, hydrothermal vents.

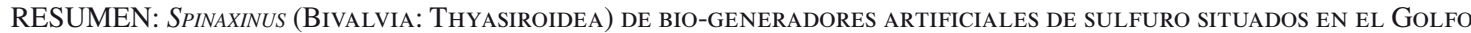
DE MÉJICO Y EN FUENTES HIDROTERMALES DE LAS ISLAS FIJI: QUIMIOSIMBIOSIS Y TAXONOMÍA. - En este trabajo se describen dos especies nuevas de tisárido del género Spinaxinus (S. emcatus Oliver n. sp. y S. phrixicus Oliver n. sp.) encontradas respectivamente en el Golfo de Méjico y en el sureste del Pacífico. Se comparan estas dos especies nuevas con la especie tipo del género, S. sentous Oliver y Holmes, 2006 descrita en el Este del Atlántico. Para describir estas dos especies, se observaron ejemplares vivos recolectados sobre bio-generadores artificiales de sulfuro situados en la parte alta de la plataforma continental de Louisiana, en el Golfo de Méjico. Las observaciones realizadas de las branquias de Spinaxinus y la caracterización genética de las bacterias simbiontes en estos ejemplares confirmaron que Spinaxinus es un género quimiosintético que contiene bacterias quimioautótrofas cercanas a las Gammaproteobacterias responsables de la oxidación del sulfuro. También se recolectaron ejemplares vivos de fuentes hidrotermales situadas en las Islas Fiji y en 'Lau Back Arc Basins' ambas localizadas en el Pacífico suroccidental. La especie atlántica de Spinaxinus se encontró en dos tipos de sustratos artificiales mientras que parece que esta especie no se encuentra en ambientes naturales equivalentes como serían las surgencias frías y las fuentes hidrotermales. La distribución aparentemente limitada de la especie atlántica se discute en relación con la distribución de $S$. phrixicus en las fuentes hidrotermales del Pacífico.

Palabras clave: Thyasiroidea, taxonomía, quimiosimbiosis, sustratos artificiales, fuentes hidrotermales. 


\section{INTRODUCTION}

The genus Spinaxinus was erected from specimens collected from the wreck of a cargo vessel that sunk off the Atlantic coast of Spain in 1979 and lay at $1160 \mathrm{~m}$. During salvaging from 1991-1992 a community of organisms, including vestimentiferan worms and bivalves, was found living on the cargo of sisal bales, sunflower seeds and beans (Dando et al. 1992). The thyasirids collected were described as Spinaxinus sentosus Oliver and Holmes, 2006 and were inferred to be chemosymbiotic from the substrate and associated fauna (Oliver and Holmes 2006). The associated fauna included the vestimentiferan, Lamellibrachia barhami Webb, 1969 and the mussel Idasola (Dando et al. 1992). The state of preservation was not sufficient to carry out an electron microscopy study or for molecular analysis. To date this genus has only been found in this artificial environment except for a single juvenile shell taken from a mud volcano in the Gulf of Cadiz (Oliver et al. 2011).

This paper primarily reports upon a newly discovered population of a Spinaxinus retrieved from artificial sulfide bio-generators in the Gulf of Mexico (Carney et al. 2010). The Gulf of Mexico specimens are well preserved and have allowed both morphological and molecular studies. Comparisons with the eastern Atlantic S. sentosus are restricted to shell morphology due to poor preservation. During these investigations a third species of Spinaxinus has been recognized from the Fiji Back Arc and Lau Basins. This is the species referred to by Taylor et al. (2007) as "Thyasira sp. (vent species)" and although represented by a single complete adult specimen it is described here.

\section{MATERIALS AND METHODS}

\section{Gulf of Mexico sulfide bio-generators}

\section{Rationale}

The program of device development and deployment was inspired by the report of lamellibrachid tubeworms in the decomposing agricultural cargo of the shipwreck Francois Vieljeux (Dando et al. 1992). If organic decomposition in smaller devices could similarly produce sufficient sulfide to attract and support sulfide-based chemosynthesis, then there would be an experimental tool for the study of seep community colonization and dispersal. In 1996 deployment of prototype devices in the Gulf of Mexico began, resulting in their colonization by 555 lamellibrachid tubeworms after five years (Carney unpublished data). At that time molluscs were not encountered in those prototypes. More extensive deployment has taken place since that time.

\section{Sulfide biogenerator construction}

The primary components of the devices (Fig. 1) consist of a bed of pressed alfalfa pellets sold as rab-

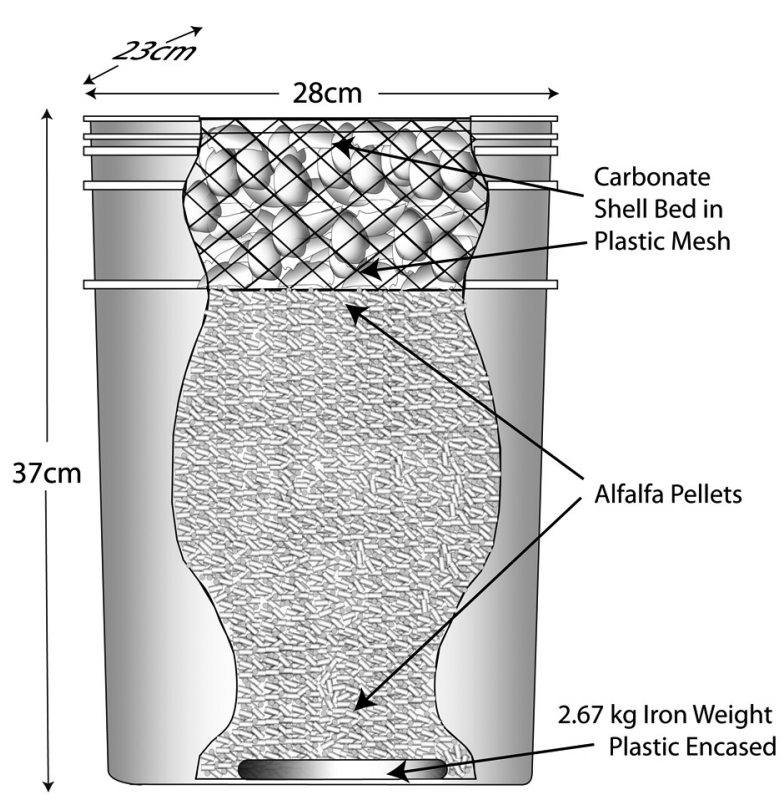

FIG. 1. - Diagram of the sulfide bio-generator deployed in the Gulf of Mexico.

bit food (Purina Rabbit Chow Complete). This chow was comprised of compressed $4 \times 10 \mathrm{~mm}$ pellets of dehydrated alfalfa with lesser amounts of other grain and soybean products. The pellets are an inexpensive source of labile plant carbon which are safe, easy to handle and unlikely to attract scavengers as a meat product might. To promote rapid initial development of a sulfide producing microbiota, sodium sulfate $\left(\mathrm{Na}_{2} \mathrm{SO}_{4}\right)$ was added to delay the onset of sulfate limitation. The bed of pellets was topped by a 12-cm layer of carbonate shells intended to simulate the hard substrate favoured for settlement by tubeworms in natural seep systems. The shells used, of the marsh clam Rangia cuneata, are available in fairly large quantities, having once been used for road paving in some coastal areas of the United States.

Two different plastic pails were used. Deployments made in August 2002 used 15-L opaque pails with a square $23 \times 23 \mathrm{~cm}$ mouth and a height of $33 \mathrm{~cm}$. Deployments made in August 2003 used 20-L translucent pails with a rectangular mouth measuring $23 \times 28 \mathrm{~cm}$ and a height of $37 \mathrm{~cm}$. A plastic encased $2.67-\mathrm{kg}$ iron weight was placed at the bottom of the pail to overcome initial positive buoyancy. The pail was then filled to within $12 \mathrm{~cm}$ of the top with rabbit chow. Five hundred grams of dry sodium sulfate was then added. The plastic mesh container of shell material was then placed on top of the rabbit chow layer and secured by drilling four holes through the edge of the mouth and placing an electrical tie through the pail and the mesh.

\section{Deployment and recovery}

The discovery of Spinaxinus was fortuitous in these tubeworm colonization experiments. The 
specimens were found in the shell layer, which had become filled with detritus of decomposed alfalfa pellets. The devices containing Spinaxinus were recovered in August 2006 by the submersible Johnson Sealink II operated by the Harbor Branch Oceanography Institution. The holotype was found in a device deployed in August 2002 on mud bottom in the vicinity of a chemosynthetic community and a brine pool. The paratypes were found in deployments made in August 2003 on a mud bottom with no known seep communities in the immediate vicinity. Sulfide and $\mathrm{pH}$ microprobe profiles from the biogenerators confirmed that the intended hydrogen sulfide generation was active and that they were functioning as artificial sulfidic systems (Bertics and Ziebis unpublished data).

\section{Molecular characterization of host and associated bacteria}

DNA was extracted from gill tissue of three specimens using DNA Blood and Tissue Kit (QIAGEM, CA). Host gene encoding 28S rRNA was amplified using the primer combination LSU-900f/LSU-1600r (Williams et al. 2004). Bacterial genes encoding 16S rRNA and adenosine 5'-phosphosulfate (APS) reductase were amplified using the primer combinations 27F/1492R (Lane 1991) and APRA_1FW/APRA_5RV (Meyer and Kuever 2007), respectively. PCR products were sequenced directly at GATC Biotech (Constanz, Germany); as sequence chromatograms displayed no ambiguity such as double peaks, no additional cloning step was added for 16S rRNA and APS

Sequences were compared with sequences available in Genbank using BLAST (http://www.ncbi. nlm.nih.gov) (Altschul et al. 1997). The 16S rRNA phylogenetic relationships were reconstructed using maximum likelihood (ML) with the PHYLIP package (Felsenstein 1995).

\section{Southwest Pacific material}

Material of Spinaxinus from the SW Pacific was that used by Taylor et al. (2007) and housed in the Swedish Museum of Natural History. It originates from the TUI MALILA Expedition (TUIM) during 2005 of the Fiji Back Arc and Lau Basins aboard the RV Melville and utilizing the ROV Jason. The specimens came from two sites, the White Lady Vent and Hine Hina Vent; background data on these sites can be viewed at http:// www.interridge.org/irvents/content/white-lady and http://www.interridge.org/irvents/content/hine-hina.

\section{Shell morphology}

Shell images were made using a computer-aided digital photographic system powered by AutoMontage ${ }^{\mathrm{TM}}$ and by scanning electron microscopy with a JEOL Neoscope.

\section{Gross anatomy}

The specimens had previously been fixed in and stored in $100 \%$ ethanol, subsequently stained with rose bengal or methylene blue. The shell was dissected away from the soft tissues and the anatomy was viewed and dissected from the left side. Images were made using a computer-aided digital photographic system powered by AutoMontage ${ }^{\mathrm{TM}}$.

\section{Critical Point Drying and SEM examination}

For SEM examination the tissues were dissected from the shell and the ctenidia were excised and sliced transversely with a razor blade into several pieces. The tissue pieces were dehydrated in $100 \%$ ethanol and critical point dried. The specimens were then mounted on stubs, sputter coated with gold and examined using a Jeol Neoscope scanning electron microscope.

\section{SYSTEMATICS}

Class BIVALVIA Linnaeus, 1758

Subclass HETERODONTA Neumayr, 1884

Order VENEROIDA H. and A. Adams, 1856

Superfamily THYASIROIDEA Dall, 1900

Family THYASIRIDAE Dall, 1900

Genus Spinaxinus Oliver and Holmes, 2006

Type species: Spinaxinus sentosus Oliver and Holmes, 2006 OD

Spinaxinus emicatus Oliver, n. sp.

Type material. Holotype $1 \mathrm{sp}$., Louisiana slope, Gulf of Mexico, $27^{\circ} 44.1292^{`} \mathrm{~N} 91^{\circ} 15.2858^{`} \mathrm{~W}, 643 \mathrm{~m}$, NMW.Z.2013.1.1; Paratypes 4 sp., as holotype; 4 sp., Louisiana slope, Gulf of Mexico, $27^{\circ}$ 45.9164 ${ }^{\circ} \mathrm{N} 91^{\circ} 06.7308^{\prime} \mathrm{W}, 584 \mathrm{~m}$, NMW.Z.2013.1.2 and USNM All leg. R. Carney.

Comparative material. Spinaxinus sentosus, Holotype and paratypes, hold of the cargo ship Francois Vieljeux approx. 30 miles west of Vigo, Spain, 42 $7.95^{\prime} \mathrm{N} 9^{\circ} 26.95^{`} \mathrm{~W}, 1160 \mathrm{~m} .1992$. NMW.Z.2002.108.1/2. Thyasira oleophila, Louisiana slope, Bush Hill GC-185, 2746.941 $\mathrm{N} 91^{\circ} 30.479^{\prime} \mathrm{W}, 1738$ feet $(529 \mathrm{~m})$, FMNH307755. Thyasira conia, Syntypes, San Juan Harbour, Porto Rico, 310 fathoms (567 m). USNM 108949.

Diagnosis. A moderately large thyasirid with a spicate periostracum, uncalcified periostracal spines becoming black in larger individuals. Compressed, subcircular in outline, beaks close to the midline, posterior sulcus weak, posterior area relatively wide. Residual anterior protractor muscle scars absent. Ctenidia with laminar filaments, abfrontal region expanded, lined with bacteriocytes with a glycocalyx.

Description (Figs 2-5). Shell to $21.7 \mathrm{~mm}$ in length, holotype $19.4 \mathrm{~mm}$ (Fig. 2, Table 1). Thin, fragile. Equivalve. Not inflated. Beaks not elevated, prosogyrate. Outline variable (Fig. 3), height and length approximately equal but some longer than high and some higher than long; approximately subcircular, most expanded poste- 
TABLE 1. - Shell measurements.

\begin{tabular}{lccc}
\hline & Length & Height & Tumidity \\
\hline Holotype & 19.4 & 19.6 & 4.8 \\
Paratype & 21.7 & 20.3 & 6.4 \\
Paratype & 16.1 & 16.2 & 4.0 \\
Paratype & 14.0 & 14.8 & 3.7 \\
Paratype & 13.7 & 13.6 & 3.5 \\
Paratype & 15.8 & 13.4 & 4.4 \\
Paratype & 18.5 & 17.6 & 5.7 \\
Paratype & 11.7 & 10.7 & 2.8 \\
Paratype & 9.5 & 8.8 & 2.1 \\
\hline
\end{tabular}

riorly and narrower anteriorly; posterior dorsal margin long, curved, marking the very narrow and shallow escutcheon; posterior margin subtruncate weakly sinuate; ventral and anterior forming a continuous curve to meet a long lunule (Fig. 3C). Escutcheon very narrow, auricle absent (Fig. 3B, C). Posterior sinus shallow but distinct, setting off a relatively wide posterior area. Ligament opisthodetic on a deeply sunken resilifer just over half the length of the escutcheon. Hinge teeth absent. Sculpture of irregular commarginal lines and growth stops, microsculpture weakly rippled (Fig. 4D). Periostracum persistent, greyish to olive-buff in colour, minutely spicate (Fig. 5A); in larger shells on the central areas (Fig. 4B) the uncalcified spines are short dark, almost black, in colour, on the margins (Fig. 4C, 5B) the spines are dense, long with longitudinal strengthening ridges (Fig. 5C). Internal muscle scars apparent (Fig. 2D), anterior adductor scar long and almost twice the area of the posterior scar, separation from the pallial line slight; posterior adductor scar narrow, partly on the posterior area; pallial line thick, entire.

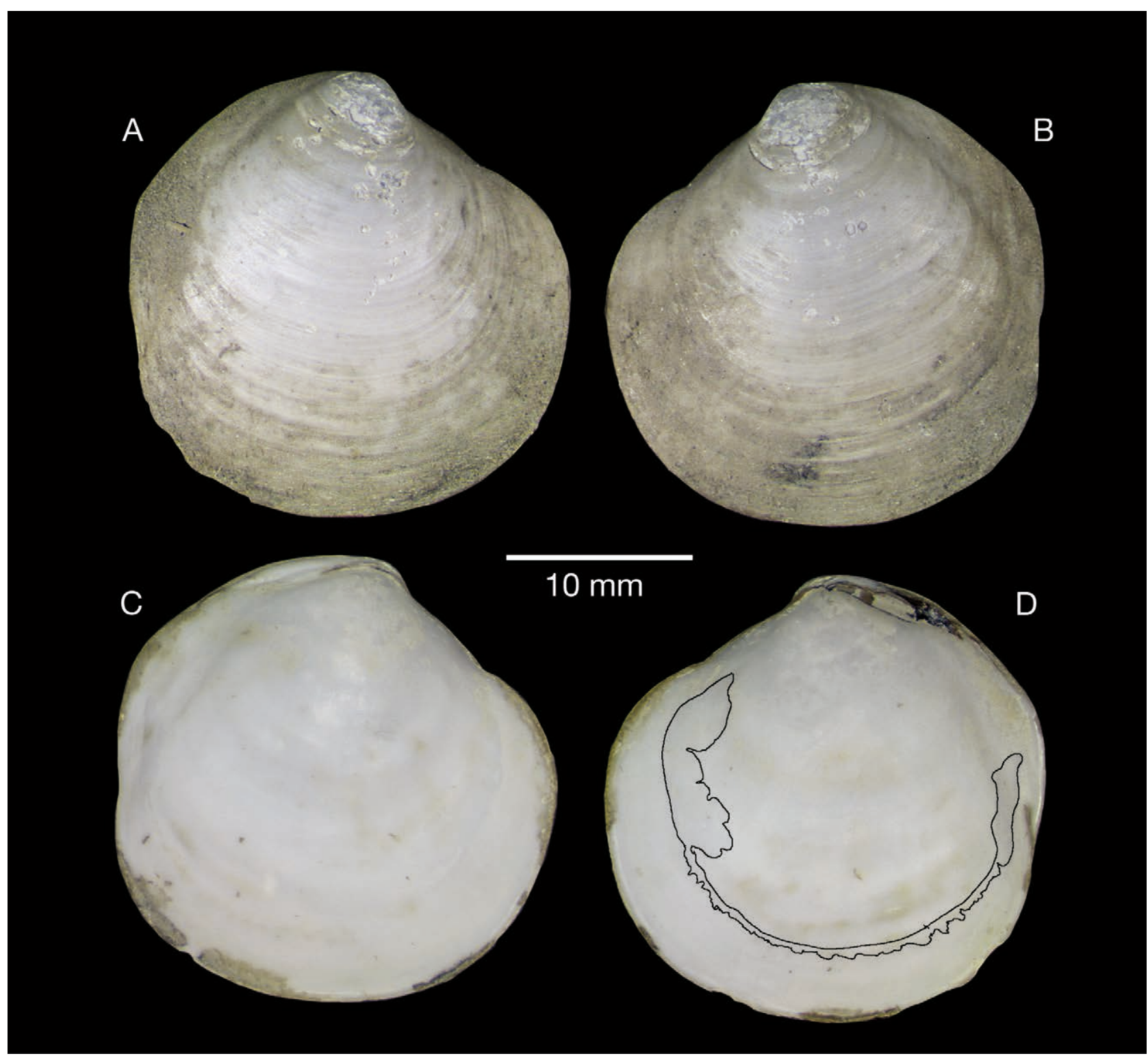

FIG. 2. - Spinaxinus emicatus n. sp., Holotype, NMW.Z.2013.1.1. A and D, right valve, internal view with outline of muscle scars superimposed; B and C, left valve. 


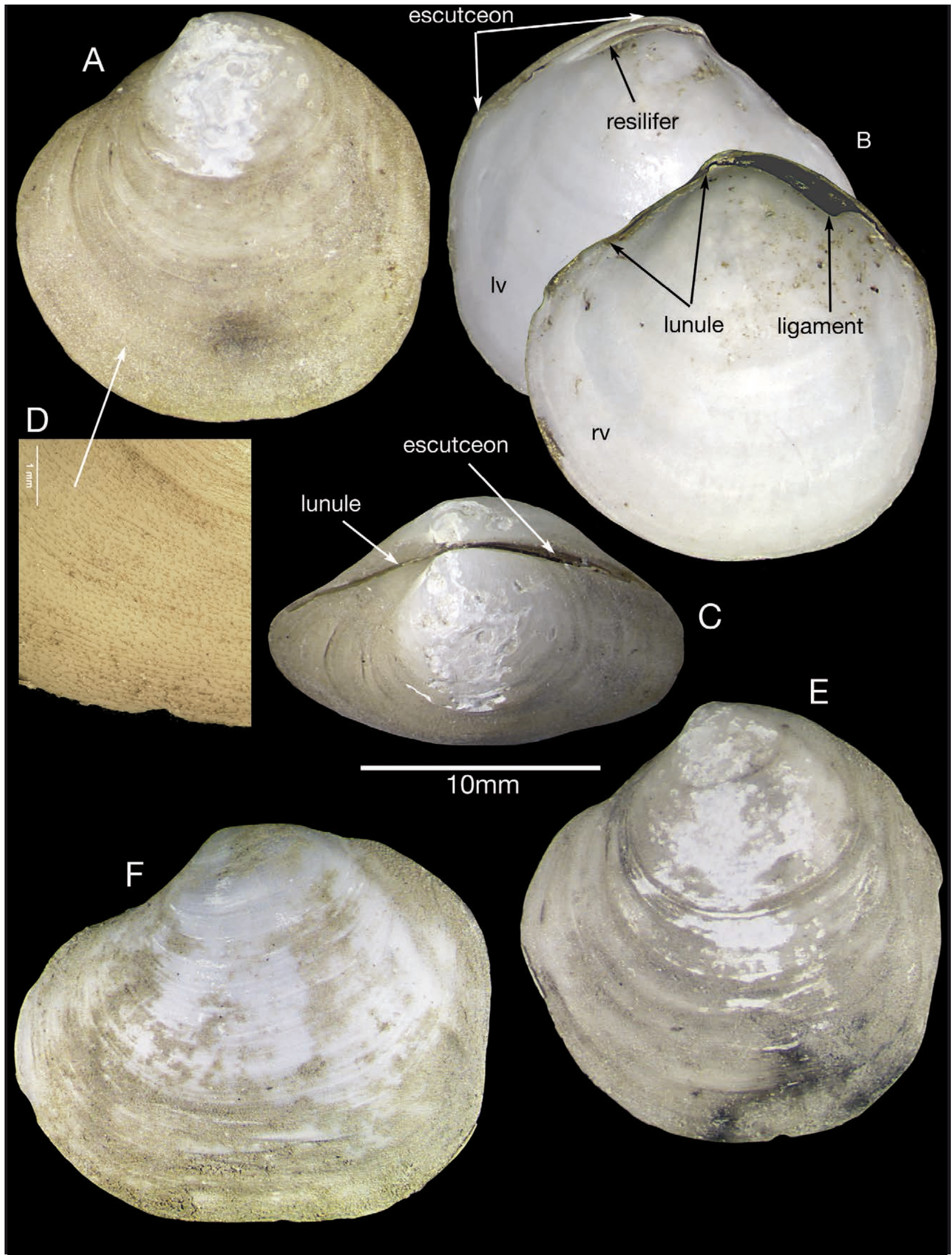

FIG. 3. - Spinaxinus emicatus, Paratypes to show variation in outline. 


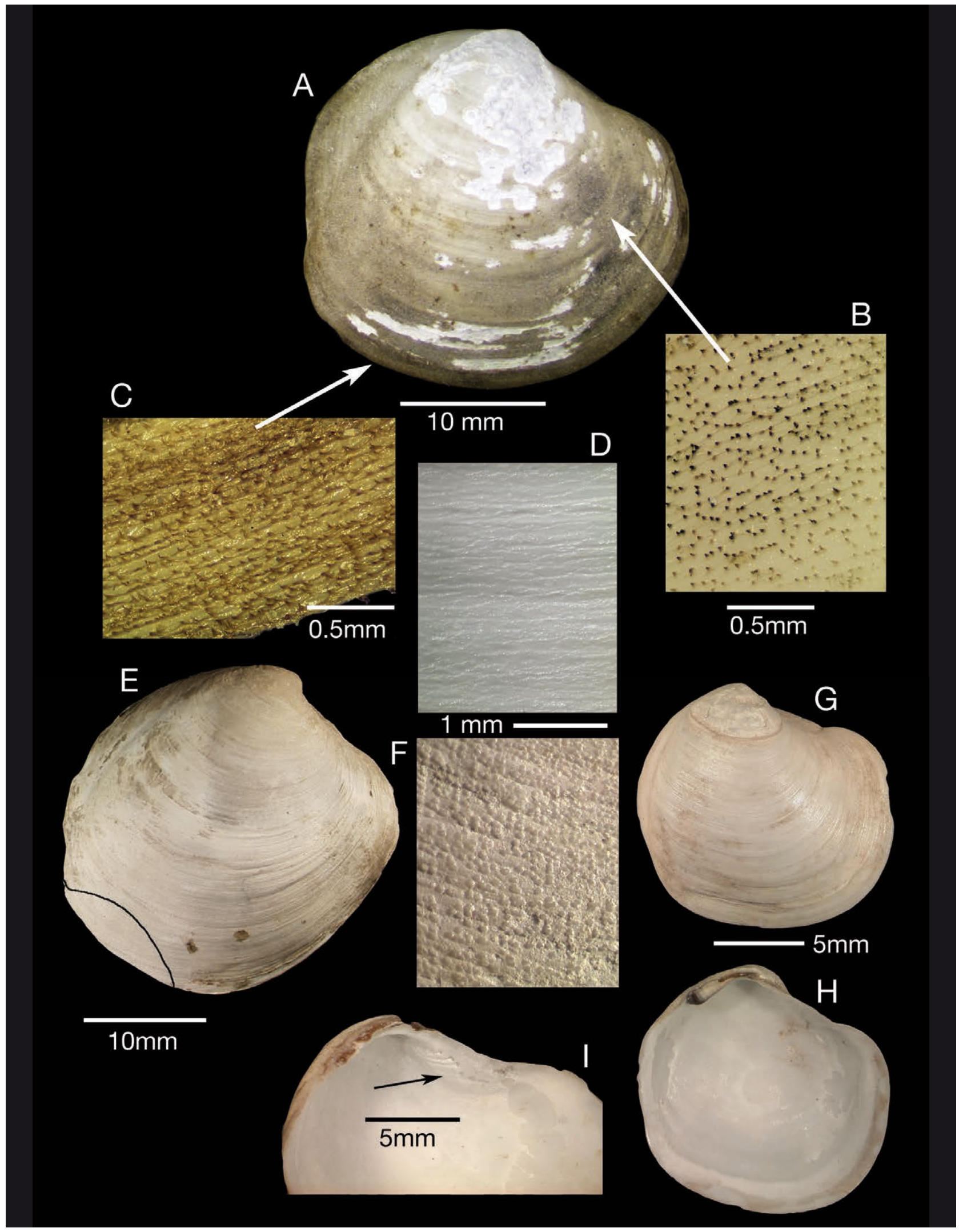

FIG. 4. - A-D Spinaxinus emicatus: A, right valve of largest specimen; B, periostracal spines on middle area; C, periostracum on margins; D, shell surface with periostracum removed. E-F, Thyasira oleophila, Louisiana slope: E, a right valve; F, surface detail. G-I, Spinaxinus sentosus, off Vigo, Spain: G-H, holotype; I, detail showing residual pedal retractor scars. 

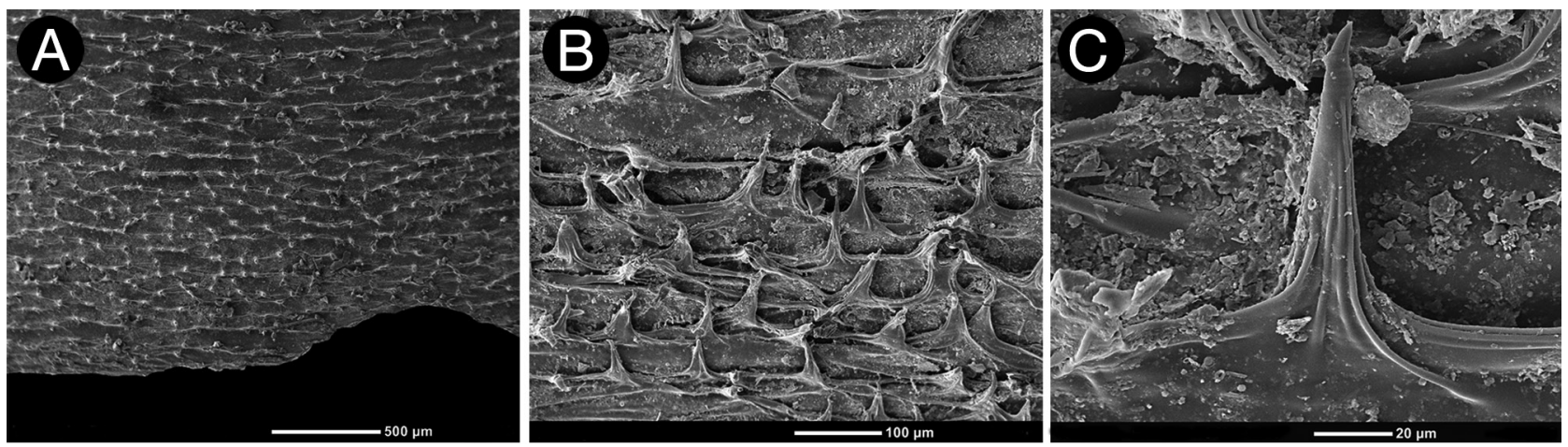

FIG. 5. - Scanning electron micrographs at progressive magnifications of the periostracum of Spinaxinus emicatus.

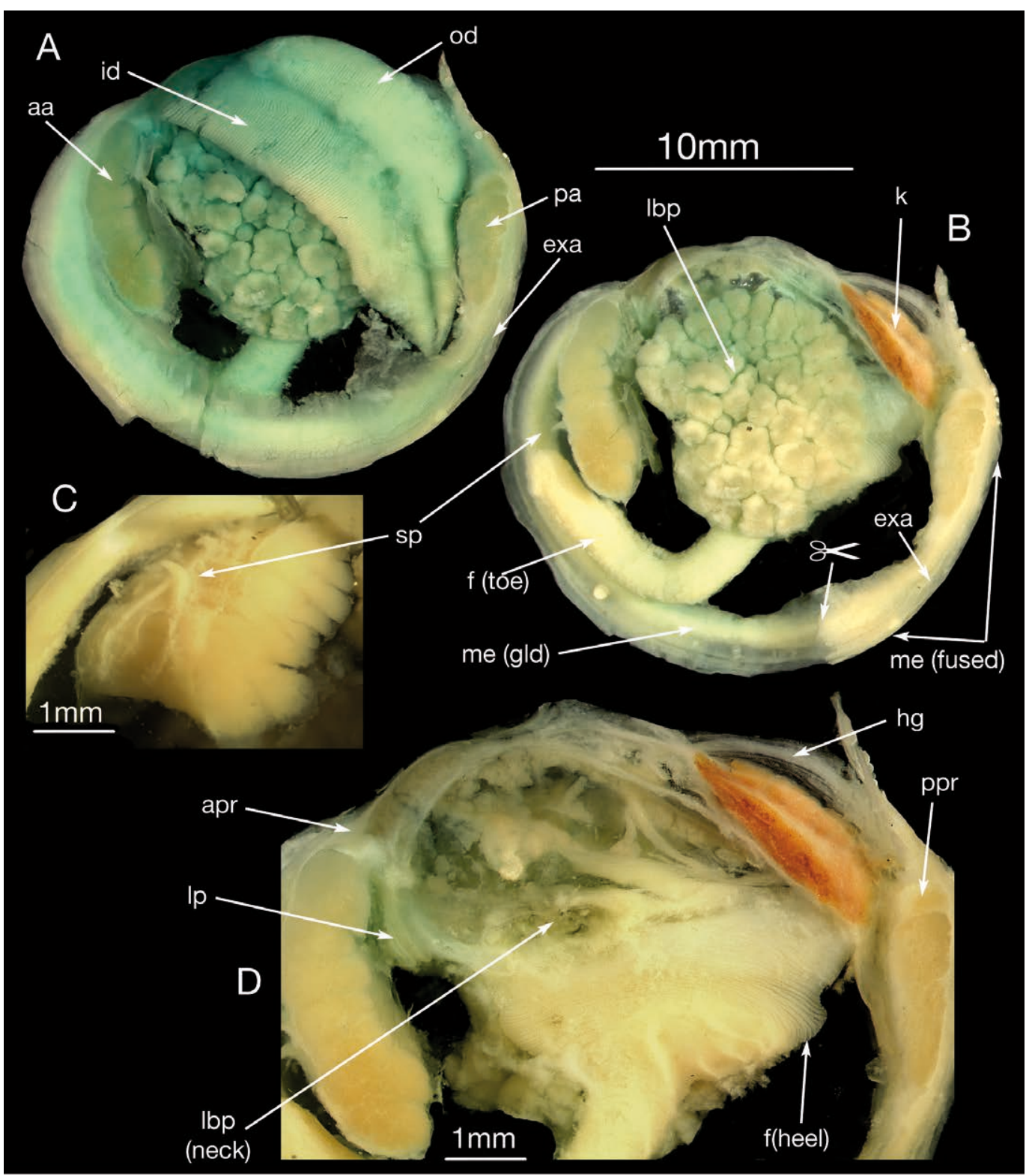

Fig. 6. - Gross anatomy of Spinaxinus emicatus. A, with mantle removed; B, with mantle edge and ctenidium removed; C, sensory papilla on the outer face of the anterior adductor muscle; D, with lateral pouch removed and partial dissection of the visceral mass.aa, anterior adductor muscle; apr, anterior pedal retractor muscle; exa, exhalant aperture; f, foot; hg, hind gut; id, inner demibranch; k, kidney; lbp, lateral body pouch; lp, labial palp; me (gld), glandular area of mantle edge; me, mantle edge; od, outer demibranch; pa, posterior adductor muscle; ppr, posterior pedal retractor muscle; sp, sensory papilla. 

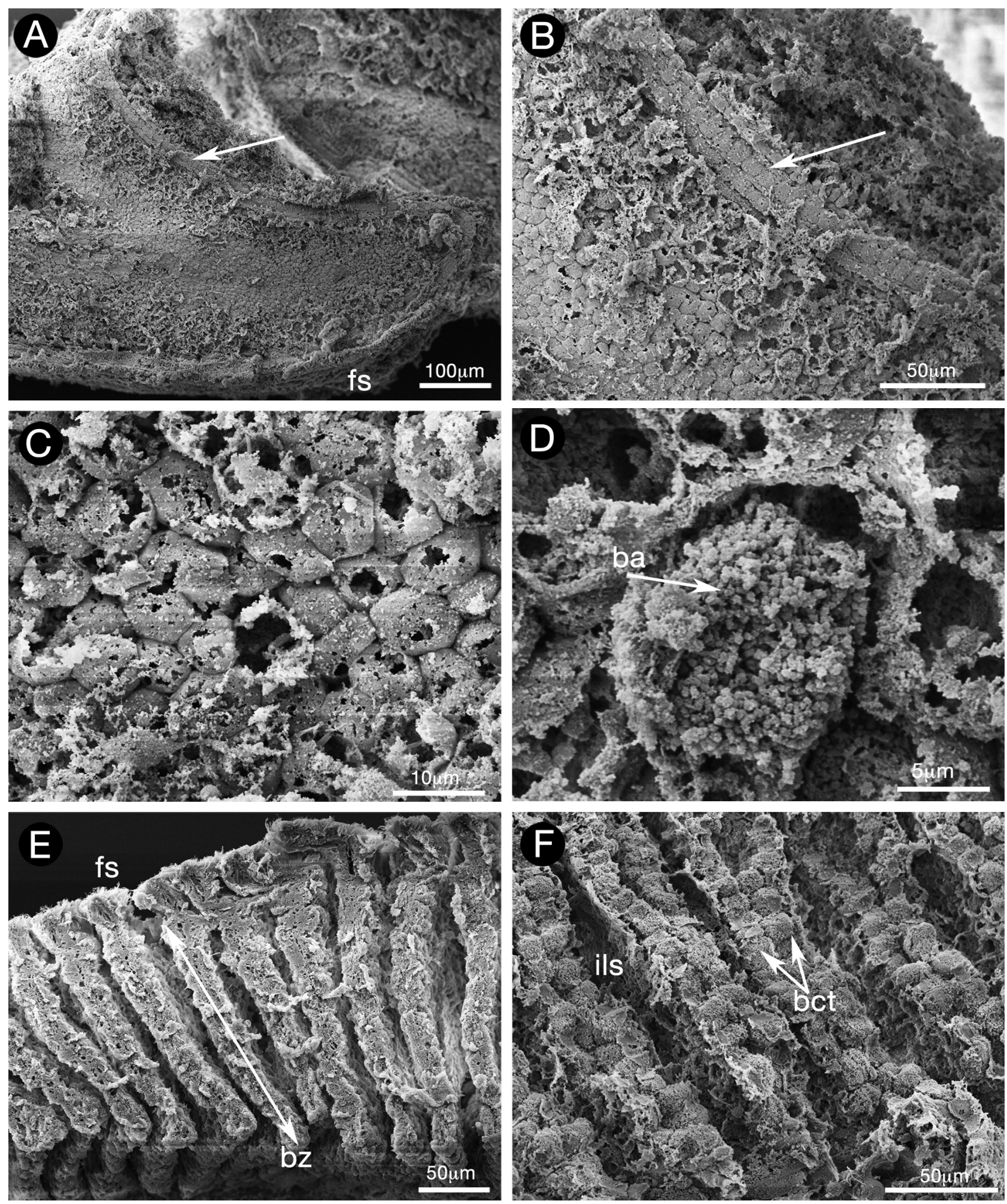

FIG. 7. - Scanning electron micrographs of the ctenidium of Spinaxinus emicatus. A, lateral face of a lamellar filament, (fs) frontal surface, (arrowed) inner surface with double layer of cuboidal cells arrowed. B, detail of A showing polygonal pattern of bacteriocytes. C, surface of bacteriocytes with glycocalyx coating. D, single bacteriocyte with glycocalyx eroded and revealing bundle of bacteria (ba). E, transverse slice of a series of filaments showing greatly elongated bacteriocyte zone (bz). F, broken abfrontal edges showing large bacteriocytes (bct), interlamellar spaces (ils).

Gross anatomy (Fig. 6). Mantle edge free except for a short siphonal opening posteriorly, inner fold thick and glandular (Fig. 6B). Anterior adductor muscle large, elongate with a sensory papilla at one third its 
length on the outer face (Fig. 6C); posterior adductor muscle narrow; anterior and posterior pedal retractor muscles attached above and next to their respective adductor muscles (Fig. 6A). Foot vermiform (Fig. 6B), long; heel indistinct (Fig. 6D). Ctenidia with outer and inner demibranchs (Fig. 6A). Labial palps narrow lacking sorting ridges (Fig. 6D). Lateral body pouches large, tubules irregularly cuboidal (Fig. 6B), joined to stomach ventrally (Fig. 6D). Stomach small, details destroyed by removal of lateral pouch, mid-gut and hind gut present. Kidneys large, bright orange in colour due to dense granular contents (Fig. 6B, D).

Gill morphology (Fig. 7). The ctenidia are composed of both outer and inner demibranchs, the outer slightly shorter but extending more dorsally to expose the majority of the inner demibranch. The filaments are reflected with their abfrontal regions greatly extended to form a lamella Fig. 7A). The outer surface is ciliated (Fig 7A, E, fs) and there is a narrow intermediary zone in front of a greatly extended abfrontal zone (Fig 7E, bz arrowed). The inner edge of each lamella is lined by a double row of large cuboidal bacteriocytes (Fig. $7 \mathrm{~A}, \mathrm{~B}$, arrowed). The abfrontal zone of each lamella is lined on both sides by a layer of polygonal bacteriocytes (Fig. 7F, bct), each covered by a glycocalyx (Fig. 7C). Where the glycocalyx is damaged or broken away a dense bundle of bacteria is seen filling each cell (Fig. $7 \mathrm{D}, \mathrm{ba})$. The bacteria are small, and although preservation is not good, they appear to be ovoid and less than $1 \mu \mathrm{m}$ in diameter.

Molecular characterization. All three specimens examined shared the same partial 28S rRNA-encoding sequence that showed $99 \%$ similarity (704/707 bp) with Thyasira sp. STW-2006 (AM392436), a vent species from Fiji Back Arc Basin. Unfortunately, no molecular data are available for Spinaxinus sentosus and its relationship with this new species cannot be addressed.

Etymology. From the Latin emico, "to appear suddenly" (from Brown 1956); referring to the unexpected appearance in the colonization experiments.

Differential diagnosis. Species discrimination in thyasirids has been based primarily on shell characters but can be difficult due to the relatively few shell characters available, as a consequence of the lack of a complex hinge dentition and shell sculpture. However, shell morphology is the basis of most species descriptions and remains widely used (Oliver and Killeen 2002, Zelaya 2010, Keunig 2010, Coan and Valentich Scott 2012, Oliver and Drewery 2013). Only combined morphology and molecular data using proper markers on large numbers of specimens from both sides of the Atlantic might allow unambiguous delimitation of species, although one must also keep in mind the pitfalls of molecular species delimitation (sampling bias and inter-specific divergence threshold). Future modifications of our conclusions may come with additional data from larger samples and from molecular data such as those demonstrated by Lorien et al. (2010) for bathymodiolines. However, we do not have material of the type species S. sentosus fixed appropriately for molecular study, and given the transient nature of the type locality it is unlikely that such data will ever be forthcoming; therefore, we must resort to comparative shell morphology. Variation in bivalve shell morphology has often been regarded as allometric or ecophenotypic. In thyasirids allometric changes occur early in the growth stages over the first 1-3 mm (Oliver and Killeen 2002) and are therefore unlikely to account for the differences seen here between S. sentosus and S. emicatus. Small differences in shell form have often been dismissed as ecophenotypic and this is certainly true for many epifaunal bivalves (Oliver and Holmes 2006) but less so for infaunal taxa, in which small differences are now being found to be significant as species characters (Taylor and Glover 2005).

The spicate periostracum is characteristic of the genus Spinaxinus and the only other known Atlantic species in the genus is S. sentosus (Fig. 4G-I) from off Spain. A third species from the Southwest Pacific is described and differentiated below.

In both Atlantic species the marginal spines are long, with longitudinal reinforcing ridges, but in $S$. emicatus the spines over the median area are persistent and prominent, becoming almost black in colour (Fig. 4B). The two species differ in shell shape, with S. sentosus being more oblong, so the length to height ratio is greater, and more oblique because the length to anterior length ratio is lower (Fig. 8A); the escutcheon is proportionately shorter and the posterior area is narrower (Fig. 8C). In S. sentosus accessory anterior pedal retractor scars are present (Fig. 4I) but they are absent in S. emicatus. In shell morphology alone the Gulf of Mexico and eastern Atlantic samples can be regarded as distinct species.

The conclusion that the Gulf of Mexico and eastern Atlantic samples represent different species is further supported by the biogeography of thyasirids, which have no species in common between the two regions. The Gulf of Mexico is relatively poor in thyasirids, with the deep-water taxa T. oleophila Clarke, 1989, T. conia Dall and Simpson, 1901, Conchocele disjuncta Gabb, 1866 (Boss 1967) and an undescribed species of Axinulus (Oliver unpublished), all restricted to the Caribbean. Thyasira oleophila has been collected from nearby oil seeps on the Louisiana slope but does not have a spicate periostracum and its shell surface is distinctly pustulose (Figs 4E, F).

Thyasira conia Dall and Simpson, 1901 is a small species (to $6 \mathrm{~mm}$ ) and is described as having a dustlike granular surface. This species is only known from the three syntypes and on examination the surface is granular but not with a spicate periostracum. 


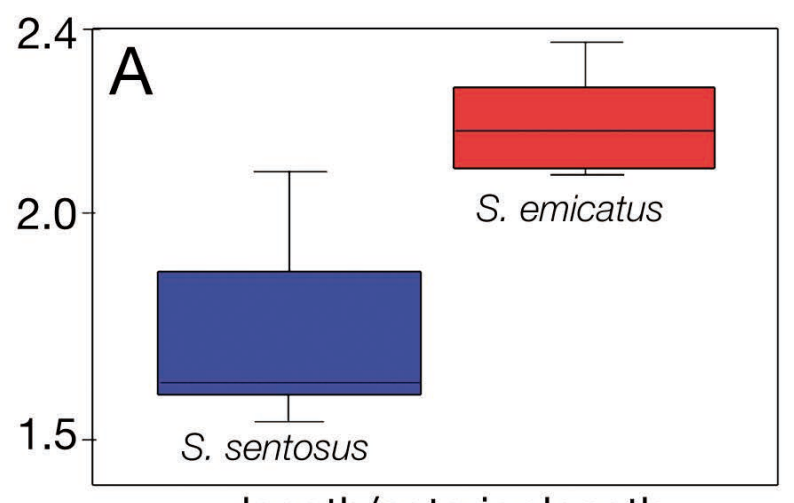

length/anterior length
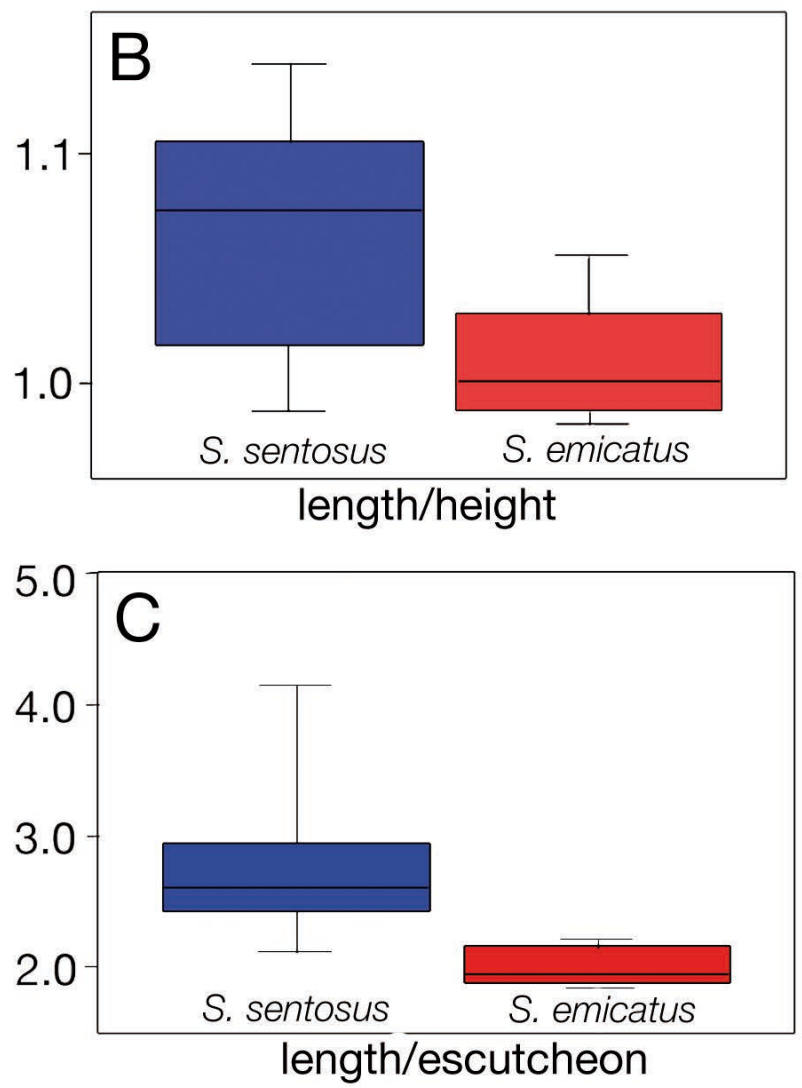

FIG. 8. - Box plots showing relative ratios of three shell dimensions for Spinaxinus emicatus and S. sentosus. A, length to anterior length; $\mathrm{B}$, length to height; $\mathrm{C}$, length to escutcheon length.

There is debate about the systematics of the shallow water T. trisinuata (d'Orbigny, 1853), which is believed by some to extend its range along the whole of the Atlantic coast of North America (Payne and Allen 1991).

Co-occurring with Spinaxinus in the Gulf of Mexico is the vestimentiferan Lamellibrachia luymesi van der Land and Nørrevang, 1975, a species not yet recorded from the eastern Atlantic and not that recently discovered in the Mediterranean and described as L. anaximandri Southward et al. 2011. The initial identification of the Lamellibrachia from the Francois Vieljeux as the Pacific species L. barhami could not be confirmed from molecular data and it is more likely that it was the same as the Mediterranean species (Eve Southward pers. comm.). The issue of amphi-Atlantic distributions of seep and vent species therefore remains unresolved, and because of the morphological difference we regard the Gulf of Mexico Spinaxinus as separate from S. sentosus in the NE Atlantic.

\section{Spinaxinus phrixicus Oliver n. sp.}

Type material. Holotype, 1 sp., RV Melville/ROV Jason cruise TUIM06MV, White Lady Vent Field, Fiji Back Arc Basin, $16.99^{\circ} \mathrm{S}$ $173.914^{\circ} \mathrm{E}, 1977 \mathrm{~m}, 31$ May 2005 . Hydrothermal seep with patches of Alviniconcha, SMNH - 78311.

Other material. 1 fragment with tissue as holotype, cross reference to Genbank AM392452.1 and AM392436.1, SMNH - 78311. 1 minute sp, $1 \mathrm{~mm}$, as holotype, SMNH - 78558. 2 sh., RV Melville/ ROV Jason cruise TUIM06MV, Hine Hina, Lau Back Arc Basin, $22.534^{\circ} \mathrm{S} 176.71001^{\circ} \mathrm{E}, 1847 \mathrm{~m}$, Hydrothermal seep, in gravel with bacterial mat, SMNH - 78277 .

Comparative material examined. As under S. emicatus above.

Diagnosis. A medium-sized thyasirid with a fine spicate periostracum. Compressed, subcircular in outline with a weakly defined posterior area. Shell sculpture of few increasingly widely spaced commarginal low ridges.

Description. Shell (Figs 9A-B) length, $8.7 \mathrm{~mm}$; height, $8.2 \mathrm{~mm}$; tumidity, $4.1 \mathrm{~mm}$. Thin, fragile. Equivalve. Not inflated. Equilateral, beaks at the midline, not elevated, prosogyrate. Outline subcircular, length slightly greater than height; posterior dorsal (escutcheon) margin long, sloping steeply, almost straight, demarcating a narrow and shallow escutcheon. Posterior ventral, ventral and anterior margins forming a continuous curve to meet a short distinctly demarcated lunule. Posterior sinus indistinct, setting off a relatively wide posterior area. Ligament opisthodetic on a deeply sunken resilifer just over half the length of the escutcheon. Hinge teeth absent. Sculpture of irregular commarginal lines and growth stops, with a few distinct raised ridges, these increasingly spaced towards the ventral margin. Periostracum thin, persistent, straw coloured, microscopically spicate (Fig. 9C) and best preserved at the margins. The perisostracal spines are uncalcified. Internal muscle scars distinct, anterior adductor scar long and almost twice the area of the posterior scar, not separated from the pallial line; posterior adductor scar narrow, partly on the posterior area; pallial line thick, in distinct radial blocks, entire.

Gross anatomy (Fig. 9D). Mantle edge free except for a short siphonal opening posteriorly, inner fold thick and glandular. Anterior adductor muscle elongate slightly longer than posterior adductor muscle but twice as wide. Foot vermiform. Ctenidia with narrow outer and inner demibranchs, outer demibranch scarce- 


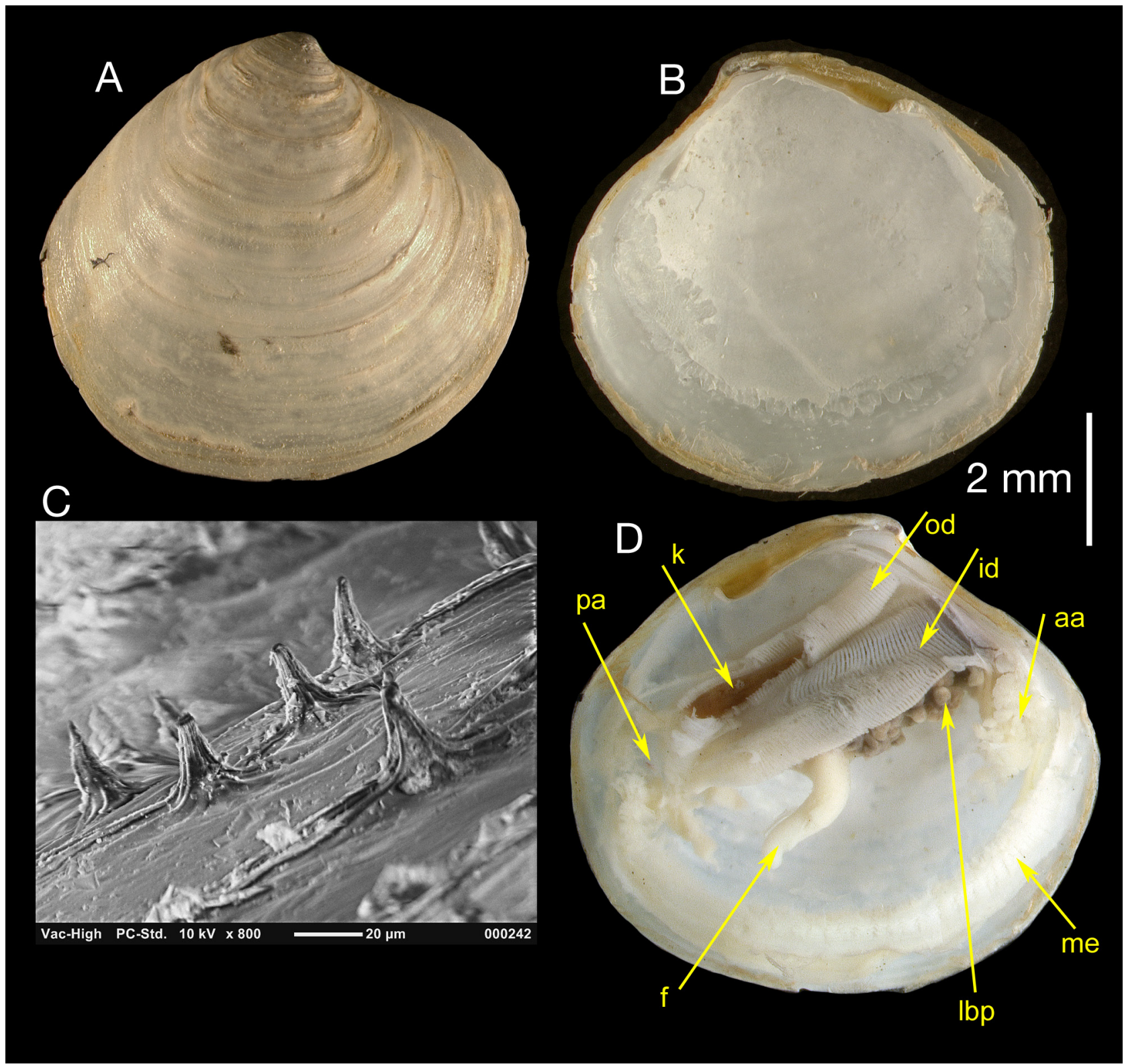

FIG. 9. - Spinaxinus phrixicus n. sp. Holotype. A exterior of right valve; B, interior of right valve; C, scanning electron micrograph of periostracal bristles; D, gross anatomy as viewed from th right side. aa, anterior adductor muscle; $f$, foot; id, inner demibranch; $k$, kidney; lbp, lateral body pouch; me, mantle edge; od, outer demibranch; pa, posterior adductor muscle.

ly overlapping inner; both with thick laminar reflected filaments. Labial palps narrow. Lateral body pouches relatively small, mostly hidden by ctenidia, tubules irregularly rounded. Kidneys large, bright orange in colour due to dense granular contents.

Etymology. From the Greek phrixikos, meaning "rippled" (from Brown 1956) and referring to the increasingly spaced commarginal ridges on the shell.

Differential diagnosis. Spinaxinus phrixicus is primarily distinguished from the Atlantic species by the presence of commarginal ridges on the shell. The periostracal bristles are of the same structure in all spe- cies of Spinaxinus but in S. phrixicus the bristles are very fine and scarcely distinguishable even under low magnification.

Anatomically all three species are similar but in $S$. phrixicus the lateral body pouches are relatively small and the tubules are rounded rather than cuboidal.

Molecular data for S. phrixicus (as Fiji Back Arc species) was obtained by Taylor et al. (2007) and there is a $99 \%$ similarity based on the $28 \mathrm{~S}$ sequence with S. emicatus. Unfortunately, an $18 \mathrm{~S}$ sequence could not be obtained, making the comparison with the data in Taylor et al. (2007) less informative at the species level. The morphological differences noted above are, in thyasirid terms, striking and could not be considered 


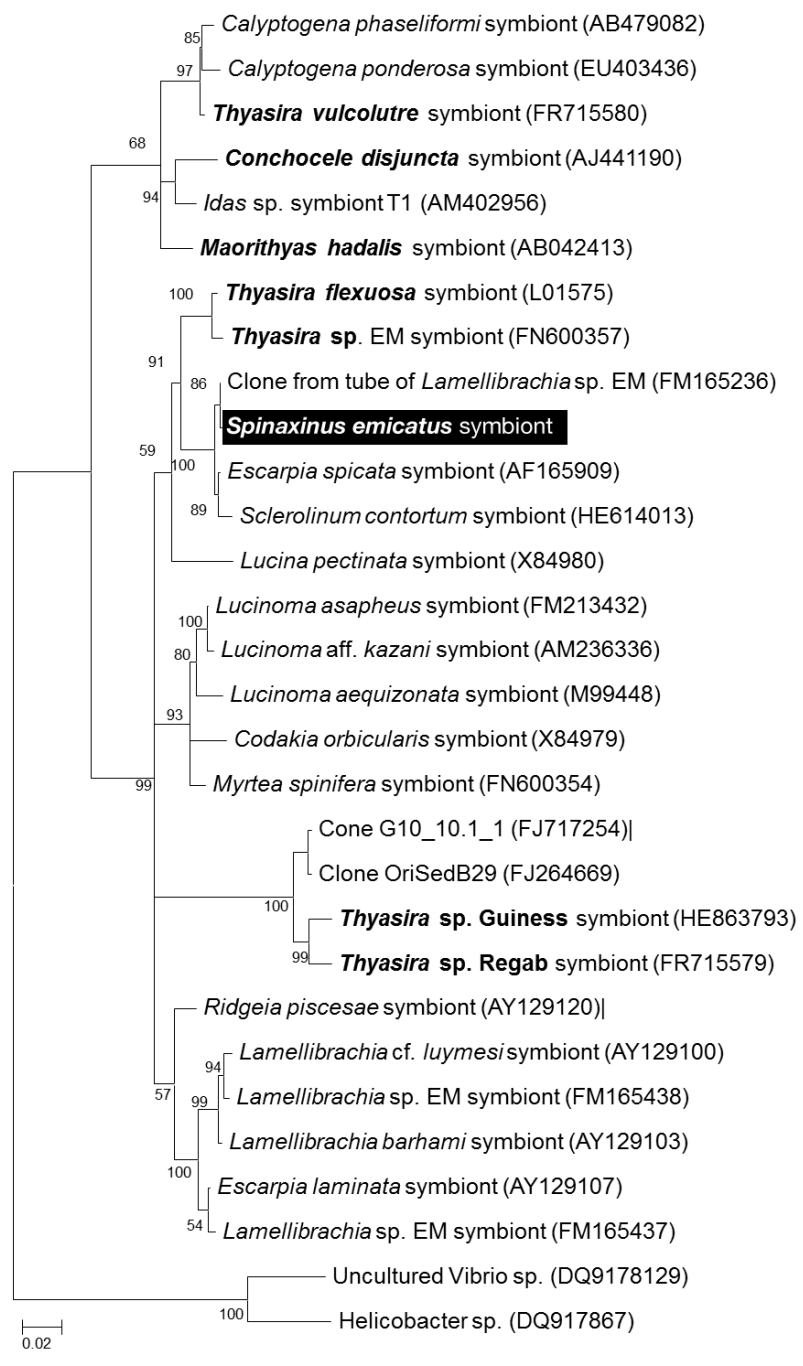

FIG. 10. - Phylogenetic tree based on the analysis of the bacterial 16 rRNA-encoding gene (1260 nucleotide positions analysed). The sequence from this study is in white on black and other thyasirid sequences are in bold. Bootstraps calculated from $500 \mathrm{NJ}$ replicates

(>50 shown). Scale bar represents $2 \%$ estimated divergence.

intra-specific. Biogeographically there is little in common between the Atlantic and Western Pacific bivalve faunas.

\section{SYMBIOTIC BACTERIA}

A single bacterial $16 \mathrm{~S}$ rRNA phylotype was retrieved from three Spinaxinus emicatus specimens and presented $99 \%$ similarity (1336/1342 bp) with a bacterial phylotype found associated with the Lamellibrachia sp. tube from the eastern Mediterranean (FM165236). Highly similar sequences included gammaproteobacterial symbionts from the tubeworms Sclerolinum contortum and Escarpia spicata, and from the thyasirid Thyasira flexuosa and the lucinid Anodontia fragilis (95-98\%). (Fig. 10)

Two phylotypes were obtained for APS reductase differing by 7 over 330 bp (no aminoacid differences), both showing $92 \%$ similarity to the APS reductase of Thyasira sp. eastern Mediterranean (FR715576).

\section{DISCUSSION}

The most intriguing aspect of this study is the sporadic occurrence of Spinaxinus in the Atlantic Ocean. Spinaxinus has now been retrieved from two artificial substrates but, with the exception of a single juvenile specimen, it has not yet been collected from other habitats, although habitats based on decaying organic matter have been poorly investigated to date (Samedi et al. 2010). The single juvenile thyasirid, tentatively identified as $S$. sentosus, came from the Gulf of Cadiz (Oliver et al. 2011), where the large numbers of thyasirids collected are, with this exception, $T$. vulcolutre (Rodrigues et al. 2008). Chemosymbiotic thyasirids have been recovered from other seep complexes such as those in the eastern Mediterranean (Rodrigues and Duperron 2011), West Africa (Duperron et al. 2012), the Gulf of Mexico (Cordes et al. 2007, 2009), Skagerrak (Dando et al. 2004) and Hakon Moseby (Gebruk et al. 2003), and are frequently found in reducing sediments throughout the Atlantic (Payne and Allen 1991, Oliver and Killeen 2002). Recent and current sampling efforts being made from seeps and vents (eg. Regab, Guiness and Hatton-Rockall) continue to produce undescribed thyasirids (Oliver and Drewery 2013) but Spinaxinus has never been recorded.

In the Pacific Spinaxinus phrixicus is associated with hydrothermal vents but in the Atlantic the only known vent species are T. southwardae from Anya's Garden (Oliver and Holmes 2006) and an undescribed fossil species from Rainbow (Lartaud et al. 2010). Vent sites are typically dominated by hard substrates where one would not expect infaunal deep burrowing species, such as thyasirids, to be commonly found.

A variety of organic falls produce reducing conditions and the association of Atlantic Spinaxinus with decaying vegetation may indicate such a natural setting. The faunal compositions of organic falls and those at vents/seeps are reported to be distinct (Bernardino et al. 2012), suggesting that different environmental markers are present. However, one well-studied thyasirid (T. sarsi) reveals that such conservatism is not universal. In Norwegian fjords $T$. sarsi has been found at sites with high organic enrichment from decaying vegetation or sewage (Dando and Southward 1986); in the Skagerrak from an active methane seep (Dando et al. 1994); in the North Sea from a weakly active pock mark (Dando et al. 1991); and in the North Sea associated with diesel contaminated drilling muds under oil platforms (Oliver and Killeeen 2002).

Faunas associated with organic falls have been the subject of a number of surveys and experiments, with that of Gaudron et al. (2010) deploying artificial traps, using alfalfa leaves along with wood and carbonate cubes. Unidentified juvenile thyasirids were retrieved from traps filled with wood but none from those with 
alfalfa grass. The thyasirids were not unique to the traps but were known from the surrounding sediments (Gaudron et al. 2010). Small thyasirids, associated with woodfalls, are also reported by Bernardino et al. (2010) but not by Pailleret et al. (2007) or by Bienhold et al. (2013). Deep-sea settings influenced by macrovegetation input have been studied, including the $\mathrm{Pu}$ erto Rico and Cayman trenches in the Caribbean, but hereto thyasirids have not been reported (Wolff 1979).

Whether Spinaxinus occurs on natural organic falls remains an open question, as very few data are available for comparison. It could be an early colonizer of natural organic falls (simulated by deployments), and might be replaced as the colonization succession proceeds.

Turning attention to the bacterial symbiont distribution, it is noted that $S$. emicatus symbionts belong to the Gammaproteobacteria and possess an APS reductaseencoding gene, which suggests a sulfur-linked metabolism. These symbionts are related to other thiotrophic bacteria associated with siboglinid tubeworms, and thyasirid and lucinid clams (Distel and Wood 1992; Rodrigues and Duperron 2011). Their 16S rRNA- and APS-encoding gene sequences are closely related to bacterial sequences found in the eastern Mediterranean cold seeps (Fig. 10) (associated with the tube of Lamellibrachia sp. and Thyasira sp. eastern Mediterranean, respectively). The $S$. emicatus-associated bacterial $16 \mathrm{~S}$ rRNA sequence is more closely related to sequences from the tube and the trophosome of several tubeworms than to other thyasirid symbionts. Symbionts are most likely acquired from the environment in Thyasiridae, and several groups of Gammaproteobacteria have been reported as thyasirid symbionts (Rodrigues and Duperron 2011). It is thus possible that symbionts of Spinaxinus result from a host shift from tubeworm-associated bacteria, or from free-living relatives of these bacteria. Tubeworm symbionts are indeed reported to occur free-living in the environment, making such a host shift possible (Harmer et al. 2008), although this hypothesis remains to be properly tested here. The symbiont distribution as illustrated in Figure 10 shows no pattern of relationship with the thyasirid host, the environmental setting or the geographical location. Indeed, the Spinaxinus symbiont clusters with symbionts from deep cold seep species (siboglinids and bivalves) but also with a shallow water species (Lucina pectina) from reducing sediments. Other seep thyasirid symbionts cluster in two widely separated groups, one including species from the NE Atlantic and NW Pacific.

Symbionts are very abundant in S. emicatus and the gill is of Type 3, as described by Dufour (2005) and reported in species such as $T$. methanophila (Oliver and Sellanes 2005) and Axinus cascadiensis (Oliver and Holmes 2007). The structure and functioning of the symbiosis in Spinaxinus would therefore appear to be no different from that in several other thyasirids previously documented to harbour sulfur-oxidizing symbionts, and thus cannot explain the unusual restricted occurrences.
Artificial substrates were deployed to answer questions such as larval dispersion, community succession and organism growth rates of cold seep organisms (Carney et al. 2010). The appearance of previously unknown species suggests that the biogenerators do not entirely mimic natural cold seeps but represent an earlier stage of development of a reducing environment.

\section{ACKNOWLEDGMENTS}

The molecular research was supported by the French ANR DeepOases, GDRE-DIWOOD. Clara Rodrigues was also supported by a postdoctoral fellowship (SFRH/BPD/64154/2009) from the Fundação para a Ciência e a Tecnologia (FCT, Portugal). The construction and deployment of sulfide biogenerators was supported by the United States National Oceanic and Atmospheric Administration Office of Ocean Exploration and Research. The crews of the R/V Seaward Johnson and the submersible Johnson Sealink provided critical technical support. V. Bertics and C-E Chow carried out initial at-sea processing of devices. Paul Dando (Marine Biological Association, Plymouth) is thanked for useful comments and discussion.

\section{REFERENCES}

Altschul S.F., Madden T.L., Schaeffer A.A., Zhang J., Zhang Z., Miller W., Lipman D.J. 1997. Gapped BLAST and PSI-BLAST: a new generation of protein database search programs. Nucleic Acids Res. 25 (17): 3389-3402

Bernardino A.F., Smith C.R., Baco A.R., Altamira I., Sumida P.Y.G. 2010. Macrofaunal succession in sediments around kelp and wood falls in the deep NE Pacific and community overlap with other reducing habitats. Deep-Sea Res. Part I 57: 708-723.

Bernardino A.F., Levin L.A., Thurber A.R., Smith C.R. 2012. Comparative composition, diversity and trophic ecology of sediment macrofauna at vents, seeps and organic falls. PLOS ONE 7(4): e33515. doi:10.1371/journal.pone.0033515

Bienhold C., Ristova P., Wenzhöfer F., Dittmar T., Boetius A. 2013. How deep-sea wood falls sustain chemosynthetic life. PLoS ONE 8(1): e53590. doi:10.1371/journal.pone.0053590

Brown R.W. 1956. Composition of Scientific Words. Smithsonian Institution Press, London and Washington, $882 \mathrm{pp}$.

Boss K.J. 1967. Biological Investigations of the Deep Sea. 31. Thyasira disjuncta (Gabb, 1866) in the Caribbean Sea. Bull. Mar. Sci. 17(2): 386-388

Carney R., Ziebis W., Bertics V., Chow C-E. 2010. A report at year 6 for long-term colonization of artificial sulfidic substrate by chemosynthetic fauna. Abstracts 12th Deep-Sea Symposium, Iceland, p.12.

Clarke A.H. 1989. New mollusks from undersea oil seep sites off Louisiana. Malacology Data Net (Ecosearch Series) 2: 122-134.

Coan E.V., Valentich-Scott P. 2012 Bivalve Seashells of Tropical West America - Marine Bivalve Mollusks from Baja California to Northern Peru. Part 1. Santa Barbara Museum of Natural History Monographs, number 6; Studies in Biodiversity number 4; Santa Barbara Natural History Museum, Santa Barbara. 598 pp.

Cordes E.E., Carney S.L., Hourdez S., Carney R.S., Brooks J.M., Fisher C.R. 2007. Cold seeps of the deep Gulf of Mexico: Community structure and biogeographic comparisons to Atlantic equatorial belt seep communities. Deep-Sea Res. Part I 54: 637-653

Cordes E.E., Bergquist D.C., Fisher C.R. 2009. Macro-ecology of Gulf of Mexico cold seeps. Annu. Rev. Mar. Sci. 1: 143-168.

Dall W.H., Simpson C.T. 1901. The Mollusca of Porto Rico. U. S. Fish Comm. Bull. 20(1): 351-524.

Dando P.R., Southward A.J. 1986. Chemoautotrophy in bivalve molluscs of the genus Thyasira. J. Mar. Biol Assoc. U.K. 66: 915-929 
Dando P.R.,Austen M.C., Burke R.J., Kendall M.A., Kennicutt M.C., Judd A.G., Moore D.C., O'Hara S.C.M., Schmaljohann R., Southward A.J. 1991. Ecology of a North Sea pockmark with an active methane seep. Mar. Ecol. Prog. Ser. 70: 49-63.

Dando P.R., Southward A.J., Southward E.C., Dixon D.R., Crawford A., Crawford M. 1992. Shipwrecked tube worms. Nature 356: 667.

Dando P.R., Bussmann I., Niven S.J., O’Hara S.C.M., Schmaljohann R., Taylor L.J. 1994. A methane seep area in the Skagerrak, the habitat of the pogonophore, Siboglinum poseidoni, and the bivalve Thyasira sarsi. Mar. Ecol. Prog. Ser. 107: 157-167.

Distel D.L.. Wood A.P. 1992. Characterization of the gill symbiont Thyasira flexuosa (Thyasiridae: Bivalvia) by use of polymerase chain reaction and $16 \mathrm{~S}$ rRNA sequence analysis. J. Bacteriol. 174: 6317-6320.

Duperron S., Rodrigues C.F., Léger N., Szafranski K., Decker C., Olu K., Gaudron S.M. 2012. Diversity of symbioses between chemosynthetic bacteria and metazoans at the Guiness cold seep site (Gulf of Guinea, West Africa). MicrobiologyOpen 12/2012; 1(4):467-480. DOI:10.1002/mbo3.47

Felsenstein J. 1995. PHYLIP (Phylogeny Inference Package) 3.57c ed. Seattle: Department of Genetics.

Gabb W.M. 1866. Cretaceous and Tertiary Fossils, Section I, Part I, Descriptions of the Tertiary Invertebrate Fossils. Palaeontology of California 2: 1-28.

Gaudron S.M., Pradillon F., Pailleret M., Duperron S., Le Bris N., Gaill F. 2010. Colonization of organic substrates deployed in deep-sea reducing habitats by symbiotic species and associated fauna. Mar. Environ. Res. 70: 1-12

Gebruk A.V., Krylova E.M., Lein A.Y., Vinogradov G.M., Anderson E., Pimenov N.V., Cherkashev G.A., Crane K. 2003. Methane seep community of the Håkon Mosby mud volcano (the Norwegian Sea): Composition and trophic aspects. Sarsia 88: 394-403.

Harmer T.L., Rotjan R.D., Nussbaumer A.D., Bright M., Ng A.W., DeChaine E.G., Cavanaugh C.M. 2008. Appl. Environ. Microbiol. 74(12): 3895-3898.

Keuning R., Schander C. 2010. Thyasira ockelmanni (Mollusca: Bivalvia: Veneroidea), a new species of Thyasiridaefrom the Norwegian Sea. Fauna Norv. 30: 21-24.

Lane D.J. 1991. 16S/23S rRNA sequencing. In: Stackebrandt E., Goodfellow M. (eds), Nucleic acid techniques in bacterial systematics. John Wiley and Sons, New York, pp. 115-175.

Lartaud F., de Rafelis M., Oliver G., Krylova E., Dyment J., Ildefonse B., Thibaud R., Gente P., Hoise E., Meistertzheim A.-L., Fouquet Y., Gaill F., Le Bris N. 2010 Fossil clams from a serpentinite-hosted sedimented vent field near the active smoker complex Rainbow, MAR, $36^{\circ} 13^{\prime} \mathrm{N}$ : insight into the biogeography of vent fauna. Geochem. Geophys. Geosys. 11, Q0AE01, doi:10.1029/2010GC003079.

Lorion J., Samadi S. 2010 Species richness, sampling bias and phylogenetics in deep-sea mussels. Cah. Biol. Mar. 51(4): 435-439.

Meyer B., Kuever J. 2007. Molecular analysis of the distribution and phylogeny of dissimilatory adenosine-59-phosphosulfate reductase-encoding genes (aprBA) among sulfuroxidizing prokaryotes. Microbiology 153: 3478-3498.

Oliver P.G., Killeen I.J. (2002) The Thyasiridae (Mollusca: Bivalvia) of the British Continental Shelf and North Sea Oilfields. An Identification Manual. Studies in Marine Biodiversity and Systematics from the National Museum of Wales, BIOMÔR Reports, 3, 1-73.

Oliver P.G., Sellanes J. 2005. New species of Thyasiridae from a methane seepage area off Concepción, Chile. Zootaxa, 1092: $1-20$.

Oliver P.G., Holmes A.M. 2006. New species of Thyasiridae (Bivalvia) from chemosynthetic communities in the Atlantic Ocean. $J$. Conch. Lond. 39(2): 175-183.
Oliver P.G., Holmes A.M. 2006. The Arcoidea (mollusca: Bivalvia): a review of the current phenetic-based systematics. Zool. J. Linn. Soc. 148: 237-251.

Oliver P.G., Holmes A.M. 2007. A new species of Axinus (Bivalvia: Thyasiroidea) from the Baby Bare Seamount, Cascadia Basin, NE Pacific with a description of the anatomy. J. Conch. Lond. 39(4): 363-376

Oliver P.G., Rodrigues C.F., Cunha M.R. 2011. Chemosymbiotic bivalves from the mud volcanoes of the Gulf of Cadiz, NE Atlantic, with descriptions of new species of Solemyidae, Lucinidae and Vesicomyidae. Zookeys 113: 1-38.

Oliver P.G., Drewery J. 2013. New species of chemosymbiotic clams (Bivalvia: Vesicomyidae and Thyasiridae) from a putative "seep" in the Hatton-Rockall Basin, northeast Atlantic. $J$. Mar. Bio. Ass. U.K. doi:10.1017/S0025315413001136

Olu-Le Roy K., von Cosel R., Hourdez S., Carney S.L., Jollivet D. 2007. Amphi-Atlantic cold-seep Bathymodiolus complexes across the equatorial belt. Deep-Sea Res. Part I 54: 1890-1911.

d'Orbigny A. 1853. Mollusques. In: Sagra M.R. Histoire Physique, Politique et Naturelle de l'île de Cuba 2: [iv] + 225-380, pls. 26-28. Bertrand Paris.

Pailleret M., Haga T., Petit P., Privé-Gill C., Saedlou N., Gaill F., Zbinden M. 2007. Sunken wood from the Vanuatu Islands: identification of wood substrates and preliminary description of associated fauna. Mar. Ecol. 28: 233-241.

Payne C.M., Allen J.A. 1991. The morphology of deep-sea Thyasiridae (Mollusca: Bivalvia) from the Atlantic Ocean. Philos. Trans. R. Soc. Lond. B 334: 481-562.

Rodrigues C.F., Oliver P.G., Cunha M.R. 2008. Thyasiroidea (Mollusca: Bivalvia) from the mud volcanoes of the Gulf of Cadiz (North-east Atlantic). Zootaxa 1752: 41-56.

Rodrigues C.F., Duperron S. 2011. Distinct symbiont lineages in three thyasirid species (Bivalvia: Thyasiridae) from the eastern Atlantic and Mediterranean Sea. Naturwissenschaften 98: 281-287.

Samadi S., Corbari L., Lorion J., Hourdez S., Haga T., Dupont J., Boisselier M-C., Richer de Forges B. 2010. Biodiversity of deep-sea organisms associated with sunken-wood or other organic remains sampled in the tropical Indo-Pacific. Cah. Biol. Mar. 51(4): 459-466.

Southward E.C., Andersen A.C., Hourdez S. 2011. Lamellibrachia anaximandri $\mathrm{n}$. sp., a new vestimentiferan tubeworm (Annelida) from the Mediterranean, with notes on frenulate tubeworms from the same habitat. Zoosystema 33(3): 245-279.

Taylor J.D., Glover E.A. 2005. Cryptic diversity of chemosymbiotic bivalves: a systematic revision of worldwide Anodontia (Mollusca: Bivalvia: Lucinidae). Syst. Biodivers. 3(3): 281-338.

Taylor J.D., Williams S.T., Glover E.A. 2007. Evolutionary relationships of the bivalve family Thyasiridae (Mollusca: Bivalvia), monophyly and superfamily status. J. Mar. Biol. Ass. U.K. 87: $565-574$

Van der Land J., Nørrevang A. 1975. The systematic position of Lamellibrachia (Annelida, Vestimientifera). Z. Zool. Syst. Evol.-forsch., Sonderheft 1: 86-101.

Williams S.T., Taylor J.D., Glover E.A. 2004. Molecular phylogeny of the Lucinoidea (Bivalvia): non-monophyly and separate acquisition of bacterial chemosymbiosis. J. Moll. Stud. 70: 187-202.

Wolff T. 1979. Macrofaunal utilization of plant remains in the deep sea. Sarsia 64: 117-136.

Zelaya D.G. 2010. New species of Thyasira, Mendicula and Axinulus (Bivalvia, Thyasiroidea) from Sub-Antarctic and Antarctic waters. Polar Biol. 33: 607-616.

Scient. ed.: M.B. Gaspar.

Received March 12, 2013. Accepted July 29, 2013.

Published online September 26, 2013. 